\title{
Struktura i ekonomski značaj državnih jamstava u Hrvatskoj u Europskoj uniji
}

Primorac, Marko; Župančić, Ivan

Source / Izvornik: Odabrani prijevodi, 2016, 7, 1 - 20

Journal article, Published version

Rad u časopisu, Objavljena verzija rada (izdavačev PDF)

https://doi.org/10.3326/op.34

Permanent link / Trajna poveznica: https:/urn.nsk.hr/urn:nbn:hr:242:812191

Rights / Prava: Attribution-NonCommercial-NoDerivatives 4.0 International/ImenovanjeNekomercijalno-Bez prerada 4.0 međunarodna

Download date / Datum preuzimanja: 2023-04-26

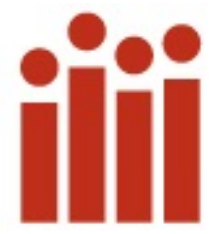

Institute of Public Finance Repository




Institut za

javne financije

Smičiklasova 2I | Zagreb

www.ijf.hr | ured@ijf.hr

T: oI/4886-444 | F: OI/48I9-365

\section{ODABRANI}

\section{PRIJEVODI}

\section{BR. 34}

\section{6 .}

ISSN I847-7445

\section{STRUKT'URA I EKONOMSKI ZNAČAJ DRŽAVNIH JAMSTAVA U HRVATSKOJ I EUROPSKOJ UNIJI}

DR. SC. MARKO PRIMORAC

MAG. OEC. IVAN ŽUPANČIĆ*
ČLANAK

JEL: H63

DOI: $10.3326 /$ op.34

\section{SAŽETAK}

U post-kriznom razdoblju, kada se zemlje suočavaju s poteškoćama u prikupljanju prihoda potrebnih za pokrivanje rashodne strane proračuna, fiskalni rizici mogu predstavljati značajnu prijetnju održivosti javnih financija. To posebno dolazi do izražaja kod javnih poduzeća i njihovih obveza, koje su često razlog povećanja javnog duga zbog poteškoća s likvidnošću. Cilj ovog rada je procjena fiskalnih rizika koji proizlaze iz državnih jamstava u Hrvatskoj i Europskoj uniji općenito. Štoviše, u radu se nastoji analizirati kretanje vrijednosti i struktura državnih jamstava $u$ Hrvatskoj u razdoblju od 2009. do prve polovice 2015. Poseban naglasak je na utjecaju državnih jamstava na izravni javni dug u kontekstu metodoloških promjena u evidenciji javnog duga.

Ključne riječi: fiskalni rizici, potencijalne obveze, državna jamstva, javni dug, Hruatska

citirati: Primorac, M. i Župančić, I., 20I6. The structure and economic significance of government guarantees in Croatia and the European Union. Financial Theory and Practice, 40 (I), str. 63-83. Dostupno na: 〈http://www.fintp.hr/upload/files/ft p/20I6/I/primorac_zupancic.pdf $>$.

Svi Odabrani prijevodi dostupni su na: http://www.ijf.hr/hr/publikacije/ca sopisi/I2/odabrani-prijevodi/III/

"Stavovi izneseni u ovom radu su isključivo stavovi autora i ne odražavaju stavove institucija u kojima su autori zaposleni. Autori zahvaljuju dvojici anonimnih recenzenata na njihovim korisnim komentarima i prijedlozima. Ovaj rad nastao je na temelju diplomskog rada kojeg je Ivan Župančić napisao pod mentorstvom dr. sc. Marka Primorca.

** Primljeno: 16. rujna 2015.

Prihvaćeno: 26. studenog 2015.

\section{Marko PRIMORAC}

Ekonomski fakultet Zagreb, Trg J. F. Kennedyja 6, IOooo Zagreb

e-mail: mprimorac@efzg.hr

Ivan ŽUPANČıć

Privredna banka Zagreb, Radnička 50, Ioooo Zagreb

e-mail: ivan.zupancicıo@gmail.com 


\section{UVOD}

Zdrave državne financije oduvijek su bile preduvjet konkurentnosti, ekonomskog razvoja i općenito dobrobiti građana. Globalna financijska kriza učinila je ovaj imperativ još važnijim. Upravljanje financijama u javnom sektoru je - kao nikada do sada - pod stalnim nadzorom rejting agencija, vjerovnika i ostalih relevantnih institucija. To se odnosi na sve razine vlasti i često postaje predmetom nadnacionalnog nadzora, kao u slučaju Europske unije (EU). Kako bi se pospješila i održala stabilnost Unije, države članice potpisale su pakt o stabilnosti i rastu, što podrazumijeva praćenje njihovih fiskalnih pokazatelja i osigurava usklađenost s kriterijima konvergencije iz Maastricht-a. To je posebice važno za nove države članice EU-a sa slabijim kapacitetima upravljanja javnim financijama. Osim toga, gospodarstva novih zemalja članica uglavnom još uvijek prolaze kroz proces tranzicije, što njihove javne financije čini još osjetljivijima na neobuzdan rast državnih obveza. Osim eksplicitnih obveza, te se države suočavaju s velikim fiskalnim rizicima koji proizlaze iz potencijalnih državnih obveza i ostalih izvora rizika.

Predmet rada jest analiza državnih jamstava na području EU-a, s posebnim osvrtom na Hrvatsku. Državna jamstva - kao vrlo važan oblik potencijalnih obveza - su jednim dijelom zanemarena, odnosno ne pridaje im se adekvatan značaj u okviru fiskalne analize. Takvim pristupom, kod ocjenjivanja financijskog položaja države, može se dobiti pogrešan dojam o njenoj stvarnoj fiskalnoj poziciji. Ovim radom nastoji se ukazati na značaj primjerenog tretmana državnih jamstava. Uspoređujući podatke za različite zemlje članice EU-a, u radu će se ispitati prelazi li razina državnih jamstava u pojedinim državama razinu njihovih izravnih eksplicitnih obveza. Osim toga, rezultati usporedne analize odgovorit će na pitanje je li razina državnih jamstava u Hrvatskoj veća od prosjeka EU-a. Glavni dio rada bit će posvećen analizi strukture državnih jamstava u Hrvatskoj, oslanjajući se - u pogledu strukture dominantno na prethodno provedeno istraživanje o veličini i strukturi državnih jamstava u Hrvatskoj (Bajo i Primorac, 20II.). U toj je analizi pokriveno razdoblje od 1996. do 2010., dok ce ovaj rad pokriti preostalo razdoblje do prve polovice 2015., te zahvatiti učinak pristupanja Hrvatske Europskoj uniji. To je važno ne samo zbog promjena koje su se dogodile u veličini i strukturi jamstava, već i zbog promjena u statističkom obuhvatu (metodologiji nacionalnih računa) državnih jamstava u Hrvatskoj (koji se postupno uskladio sa standardima EU-a).

Rad se sastoji od šest poglavlja. Nakon uvoda, objašnjava se teorijski okvir izdavanja i upravljanja jamstvima te se istraživanje stavlja $u$ kontekst aktualnih trendova $u$ upravljanju financijama i rizicima u javnom sektoru. Treće poglavlje je posvećeno državnim jamstvima na razini EU. U četvrtom poglavlju analizira se veličina i struktura državnih jamstava u Hrvatskoj, dok se u petom poglavlju diskutiraju fiskalni učinci državnih jamstava u Hrvatskoj, posebice njihov utjecaj na javni dug. Posljednje, šesto poglavlje je zaključak.

\section{TEORIJSKI OKVIR I POLITIČKI KONTEKST}

Fiskalni rizici mogu se općenito opisati kao mogućnost odstupanja fiskalnih rezultata od onoga što se očekivalo u vrijeme pripreme proračuna ili nekih drugih prognoza (Cebotari et al., 2009.). Fiskalni rizici dolaze iz mnogih izvora i u različitim oblicima, što otežava njihovo prepoznavanje i kategoriziranje za potrebe analiza i izvješćivanja. Međutim, većinu ih se može svrstati u makroekonomske i specifične rizike (IMF, 20I4.). Makroekonomski rizici uključuju nepredviđena kretanja realnog BDP-a i inflacije, cijena dobara, tečaja i kamatnih stopa, vanjske pomoći i slično. Specifični rizici proizlaze iz proračunom nepredviđenih rashoda, upravljanja imovinom i obvezama, državnih jamstava, projekata javno- 
privatnog partnerstva, izloženosti financijskom sektoru, kao i rizika vezanih uz prirodne resurse i okoliš.

U drugoj polovici 20I4., Međunarodni monetarni fond (MMF) je predstavio novi Kodeks fiskalne transparentnosti (engl. Fiscal Transparency Code) - međunarodni standard dostupnosti informacija o javnim financijama. Kodeks sadrži skup načela te se bazira na četiri stupa: (I) fiskalno izvještavanje; (2) fiskalna predviđanja i proračun; (3) analiza i upravljanje fiskalnim rizicima; i (4) upravljanje prihodima od prirodnih resursa. Stup koji je posvećen fiskalnim rizicima (sa svojih I2 načela) treba osigurati da se rizici kojima su izložene javne financije objavljuju, analiziraju te da se njima upravlja, ali i osigurati učinkovitu koordinaciju fiskalnog odlučivanja u čitavom javnom sektoru. U sklopu svoje inicijative, Odjel za fiskalne poslove (engl. Fiscal Affairs Department) MMF-a razvio je sveobuhvatan okvir za ocjenu upravljanja fiskalnim rizicima te proveo pilot projekte ocjene fiskalne transparentnosti u nekoliko država (npr. Kostarika, Irska, Rusija i Bolivija).

Upravljanje fiskalnim rizicima je relativno nerazvijeno u Europi i nije na primjeren način zastupljeno u fiskalnim zahtjevima EU-a. Točnije, fiskalni rizici u državama članicama EU-a su donedavno bili zanemarivani. Početkom 20I5., Eurostat je po prvi puta objavio podatke o potencijalnim obvezama i nenaplativim kreditima država članica EU-a (Eurostat, 2015.). Podaci su prikupljeni u sklopu Poboljšanog okvira za upravljanje ekonomskom politikom u EU (engl. Enhanced Economic Governance Package, Direktiva Vijeća 20II/85/EU), popularno nazvanog "six-pack". Prema toj klasifikaciji, potencijalne obveze obuhvaćaju jamstva, izvanbilančne obveze iz projekata javno-privatnih partnerstva i obveze poduzeća koja su pod kontrolom države, ali su klasificirana izvan sektora opće države (javna poduzeća). Međutim, detaljna struktura takvih obveza, kao i vjerojatnost njihovog nastupanja ostaje nepoznata.

Državna jamstva su dio potencijalnih, ali eksplicitnih obveza države, kojima davatelj (država) jamči vjerovniku da će mu nadoknaditi štetu koju bi pretrpio kada bi izvorni dužnik prestao otplaćivati dug (Bajo i Primorac, 20I5.). U slučaju da se jamstva protestiraju (zbog nastanka “osiguranog” slučaja), država preuzima punu odgovornost za obveze pokrivene jamstvima. Međunarodni računovodstveni standardi javnog sektora definiraju potencijalnu obvezu kao: (I) moguću obvezu koja proizlazi iz prošlih događaja i čiji nastanak se utvrđuje isključivo nastupanjem ili ne-nastupanjem jednog ili više neizvjesnih budućih događaja koji nisu potpuno pod kontrolom subjekta; ili (2) sadašnja obveza koja proizlazi iz prošlih događaja, ali nije priznata jer: (a) nije vjerojatno da će odljev sredstava koja sadrže ekonomske koristi biti potreban za podmirenje obveze; (b) iznos obveze nije moguće utvrditi s dostatnom pouzdanošću (International Federation of Accountants, 2013.: Međunarodni računovodstveni standard javnog sektora 19). Najčešći primjeri izdavanja državnih jamstava uključuju jamstva za obveze nižih razina vlasti i javnih poduzeća, razvojne banke i jamstvene agencije, projekte javno-privatnog partnerstva, kao i druge oblike suradnje države i privatnog sektora (Bajo i Primorac, 20II.).

Iako državna jamstva mogu biti korisna u smislu postizanja željenih rezultata (potpora korisnicima) bez snošenja rashoda, to je ujedno i najopasniji nedostatak jamstava. Potencijalne obveze koje proizlaze iz državnih jamstava se ne planiraju (predviđaju) u proračunu, niti se uzimaju u obzir u konvencionalnim fiskalnim analizama (Polackova, 1999.). Mogu se koristiti kao sredstvo zaobilaženja fiskalnih ograničenja zaduživanja središnje i lokalne države, zbog čega mogu imati skriven negativan učinak na fiskalnu politiku (Bajo i Primorac, 20II.). Jamstva često mogu imati potencijalno značajne fiskalne posljedice. To posebno vrijedi za zemlje koje su izdavale velike količine jamstava, kao što je to bio slučaj u mnogim 
tranzicijskim zemljama koje su pokušavale izdavanjem jamstava odgoditi troškove strukturnih reformi za budućnost (Ter-Minassian, 2005.).

Upravljanje fiskalnim rizicima na nacionalnoj razini je posebno važno u EU kao način održavanja fiskalne i općenito gospodarske stabilnosti. Međutim, vrlo malo država članica ima institucionalne okvire i kapacitete za učinkovitu kontrolu i upravljanje potencijalnim obvezama (Polackova Brixi, 2004.). Na primjer, fiskalni troškovi mogu biti značajni $u$ saveznim državama $u$ kojima postoji pretpostavka da će središnja država spašavati jedinice nižih razina vlasti koje dospiju u financijske poteškoće, kao i u tranzicijskim državama kod kojih se pretpostavlja da će država stati uz privatizirana poduzeća i financijske institucije jednom kada se izlože konkurenciji (Ter-Minassian, 2005.). U kontekstu EU-a, nove države članice su možda najsklonije gomilanju potencijalnih obveza i povezanih fiskalnih rizika (Polackova Brixi, 2004.). Posebno je zabrinjavajuće što fiskalni troškovi jamstava i drugih potencijalnih obveza najviše dolaze do izražaja u kriznim vremenima (Ter-Minassian, 2005.). Jedan od načina smanjenja rizika od takvih iznenađenja i unaprjeđenja sustava utvrđivanja vrijednosti i budžetiranja jamstava je poticanje transparentnosti o fiskalnim rizicima i njihovim potencijalnim troškovima (Thobani, 1999.; Ter-Minassian, 2015.).

\section{DRŽAVNA JAMSTVA U EUROPSKOJ UNIJI}

Prema zakonodavnom okviru EU-a, potencijalne obveze nisu uključene u obuhvat duga opće države.I Podaci o veličini i strukturi državnih jamstava za većinu zemalja članica EU-a već su neko vrijeme javno dostupni. Međutim, podaci o ostalim potencijalnim obvezama država članica EU-a prvi puta su objavljeni u siječnju 2015. To je rezultat procesa započetih u studenom 2011., kada su Europski parlament i Vijeće usvojili Poboljšani okvir za upravljanje ekonomskom politikom u EU (“six-pack”), koji zahtijeva prikupljanje i objavljivanje relevantnih informacija o potencijalnim obvezama svih podsektora opće države s potencijalno velikim utjecajem na državni proračun, uključujući jamstva, nenaplative kredite i obveze javnih poduzeća. Novi upitnik ("Dodatak o potencijalnim obvezama priložen upitniku vezanom uz proceduru prekomjernog deficita”) dodan je postojećoj skupini upitnika o proceduri prekomjernog deficita. Stoga nacionalni zavodi za statistiku godišnje dostavljaju podatke iz novog upitnika (do 31. prosinca) za prethodnu godinu, uključujući podatke o standardiziranim i jednokratnim jamstvima, projektima javno-privatnog partnerstva koji se vode izvanbilančno te nenaplativim kreditima (Eurostat, 2014.).

Standardizirana jamstva izdaju se u velikim serijama, uglavnom za vrlo male pojedinačne iznose kredita (npr. jamstva za izvozne kredite ili studentske kredite). Izdaju se u korist financijskih institucija koje odobravaju kredite prema specifičnom programu kreditiranja odobrenom od strane nacionalnih vlasti. Jednokratna jamstva daju se u posebnim slučajevima, najčešće za individualne ugovore velikih vrijednosti (npr. za velike infrastrukturne projekte ili jamstva za kredite javnih poduzeća). Takva jamstva podliježu strogom nadzoru jer bi potencijalno mogla osigurati nepoštenu konkurentsku prednost pojedinim poduzećima za čije obveze se izdaju. Stoga izdavanje takvih jamstava nadziru tijela zadužena za zaštitu tržišnog natjecanja na razini Europske unije, pa čak i Svjetska trgovinska organizacija (engl. World Trade Organisation - WTO).

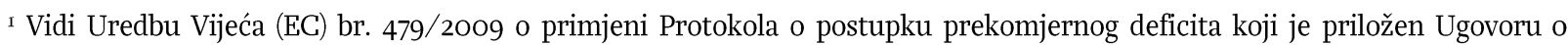
osnivanju Europske zajednice.
} 
Podaci o jamstvima u EU ne uključuju jamstva izdana u kontekstu Okvirnog sporazuma o Europskom instrumentu za financijsku stabilnost ${ }^{2}$ (engl. Framework Agreement of the European Financial Stability Facility - EFSF), jamstva nalik izvedenicama (primjerice zamjena kreditne ogluhe, engl. Credit Default Swap - CDS)3, jamstva za osiguranje depozita i slične programe kao ni državna jamstva izdana za elementarne nepogode (potrese, poplave velikih razmjera), čiju pojavu je vrlo teško pokriti putem komercijalnog osiguranja (Eurostat, 2015.).

Globalna financijska kriza značajno je utjecala na akumulaciju državnih jamstava u zemljama EU-a. Budući da su posljedice krize bile najteže $u$ financijskom sektoru, državne intervencije često su bile prizivane u cilju očuvanja kolabirajućih financijskih sustava. Sukladno tome, značajan iznos državnih jamstava nastao je u prošlosti zbog vrijednosnih papira izdanih u okviru različitih programa likvidnosti (na primjer u Grčkoj i Velikoj Britaniji). Neke zemlje članice su čak osnovale društva posebne namjene za rješavanje sve brojnijih problema s kojima se suočavao financijski sektor. U Danskoj - državno jamstvo je izdano za pokrivanje gubitaka u Roskilde Bank, u Irskoj - društvo posebne namjene odnosilo se na Državnu agenciju za upravljanje imovinom (engl. National Asset Management Agency - NAMA), u Španjolskoj - Sociedad de Gestion de Activos procedentes de la Reestructuración Bancaria (SAREB), u Francuskoj - Societe de Financement de l'Economie Française (SFEF), a u Austriji - jamstva su se izdavala za aktivnosti banke Clearingbank (Eurostat, 20I4b.). Međutim, jamstva su se također izdavala u različitim zemljama i s ciljem podupiranja drugih sektora i aktivnosti. Na primjer, Finska koristi državna jamstva za promicanje izvoza (osobito u SAD i Njemačku), ali i za domaće poslovanje malih i srednjih poduzeća kroz Finnvera (financijsko poduzeće u državnom vlasništvu koje je ujedno i službena izvozno kreditna agencija za Finsku). Jamstva su također izdavana i za dugoročne kredite društva Finavia - poduzeća u vlasništvu države koje je odgovorno za održavanje i razvoj svojih 25 zračnih luka i Finski zračni navigacijski sustav. Općenito, struktura i intenzitet izdavanju jamstava u zemljama EUa ovise o nacionalnim posebnostima, uključujući strateške ciljeve, strukturu gospodarstva (dominantnih gospodarskih sektora i onih od strateškog značaja), intenzitet državnog vlasništva, i mnoge druge čimbenike.

U 2013., jamstva kao udio u BDP-u bila su najviša u Austriji (35\%), a slijede Irska, Finska, Španjolska, Njemačka i Slovenija, dok su najniže vrijednosti zabilježene u novim zemljama članicama iz srednje i istočne Europe (Slovačkoj, Bugarskoj, baltičkim zemljama, Češkoj, Rumunjskoj), ali i u Grčkoj (grafikon I). Hrvatska je izdala jamstva u iznosu od 7,25\% BDP-a, što je niže od prosjeka EU-a od Io,5\%. Međutim, prosjek je kao pokazatelj u ovom slučaju pristran s obzirom na široku raspršenost podataka: u kontekstu medijana, koji je preciznija mjera centralne tendencije podataka u ovom uzorku, Hrvatska je pozicionirana tek malo ispod medijana, koji je iznosio 7,9\% BDP-a.

\footnotetext{
${ }^{2}$ Europski instrument za financijsku stabilnost (EFSF) je tvrtka koja je 20Io. dogovorena između zemalja koje su uvele euro i registrirana u Luksemburgu. Cilj EFSF-a je očuvanje financijske stabilnosti europske monetarne unije pružanjem privremene financijske pomoći državama članicama eurozone, u slučaju potrebe. Pomoć financira EFSF izdavanjem obveznica i drugih dužničkih instrumenata potpomognutih jamstvima država članica eurozone sukladno njihovom udjelu u uplaćenom kapitalu Europske središnje banke (za više informacija vidi: http: / / www.efsf.europa.eu/about/index.htm).

3 Jamstva nalik izvedenicama su ona jamstva kojima se aktivno trguje na financijskim tržištima i obično se tretiraju kao izvedenice te ne zahtijevaju posebne odredbe za državne transakcije na tržištima EU-a. Izvedenica se odnosi na rizik neplaćanja općenito i nije vezana uz određeni zajam ili obveznicu (Eurostat, 2013.).
} 


\section{GRAFIKONI.}

Jamstva opće države zemalja EU-a u 2013. (u \% BDP-a)

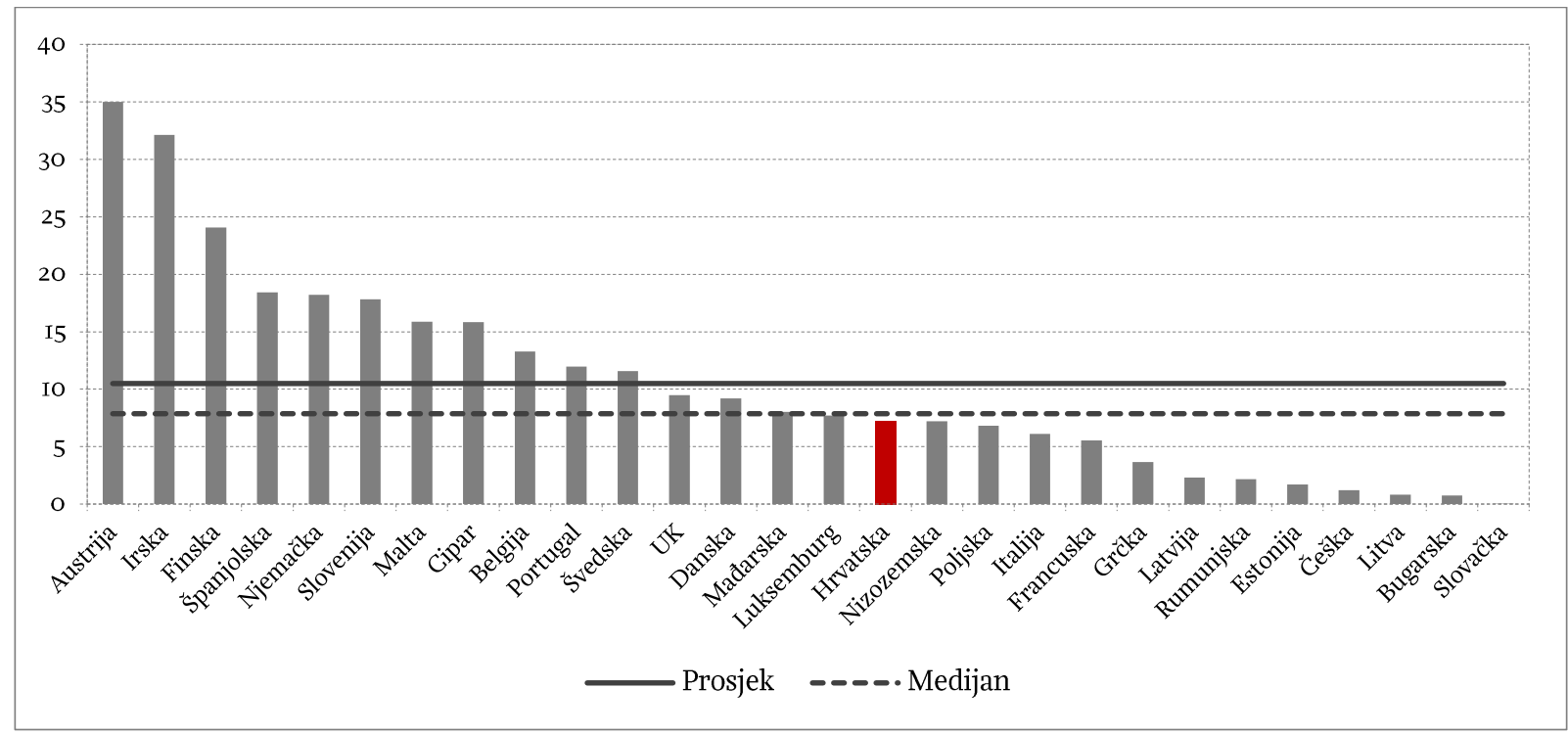

Izvor: Eurostat.

\section{GRAFIKON 2.}

Povećanje iznosa jamstava zemalja članica EU-a od 20IO. do 20I3. (u \% BDP-a)

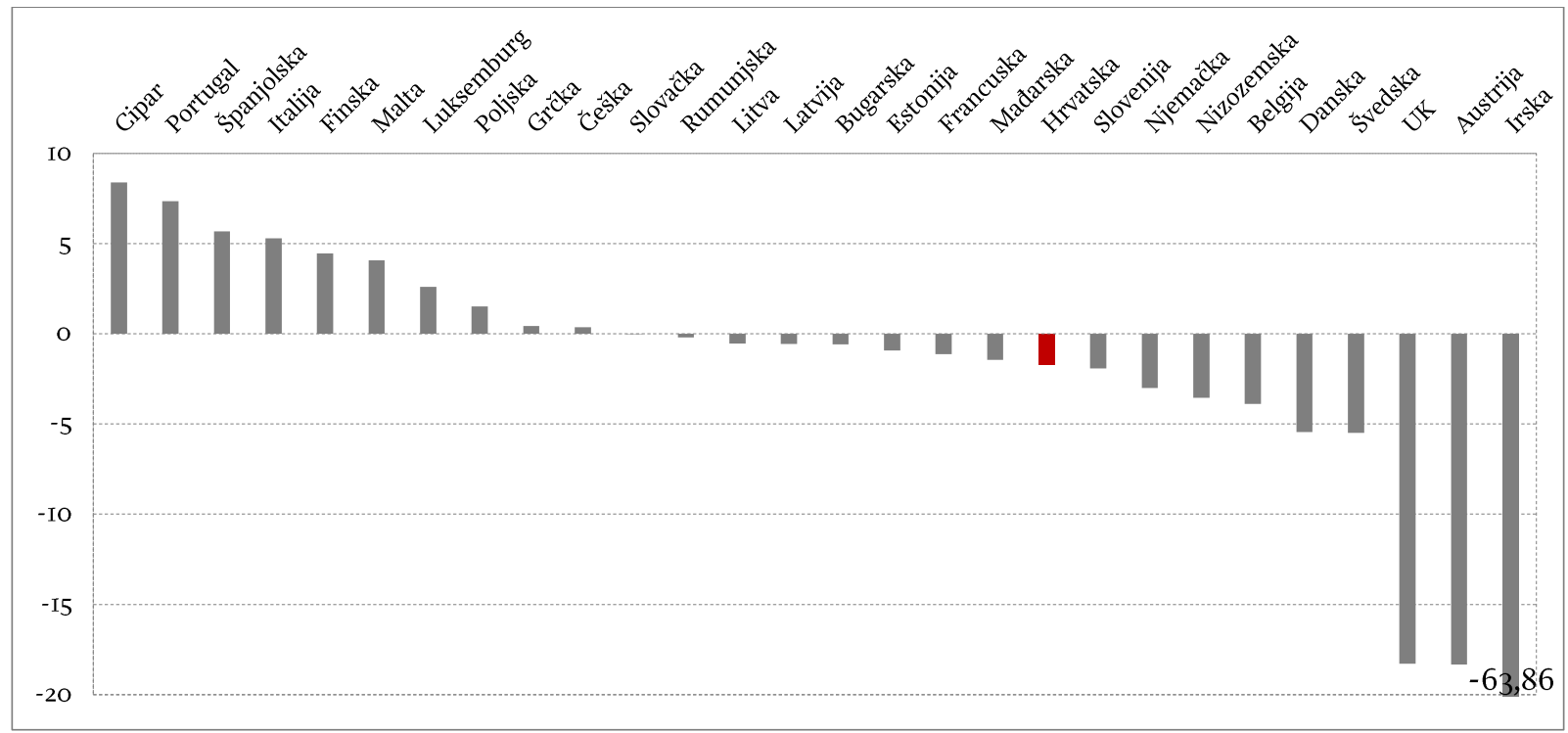

Izvor: Eurostat.

Prilično je iznenađujuće da stare zemlje članice EU-a općenito imaju veći relativni iznos jamstava od novih članica. Stare zemlje članice teže preuzeti vodeću ulogu u promicanju transparentnosti, odgovornosti i provedbi dobrih praksi u upravljanju javnim financijama. Ipak, čini se da koriste mogućnost stvaranja izvanbilančnih obveza intenzivnije od novih članica, koje su još uvijek u različitim fazama tranzicije pa se očekuje da se u većoj mjeri oslanjaju na državna jamstva. Još uvijek ostaje otvoreno pitanje imaju li stare članice EU-a zapravo više iskustva u korištenju prednosti jamstava ili neki drugi čimbenici određuju njihovu prilično visoku izloženost jamstvima. Treba međutim napomenuti da su u nekim zemljama jamstva izdana u okviru širih politika usmjerenih na spašavanje financijskih institucija pogođenih krizom. Osim toga, podaci o jamstvima su za većinu zemalja 
nepotpuni zbog parcijalnog obuhvata (Eurostat, 2015.). U Hrvatskoj, na primjer, podaci nisu dostupni za standardizirana jamstva i jamstva lokalne samouprave.

Aktualna kriza je nesumnjivo utjecala na kretanje vrijednosti državnih jamstava tijekom vremena. Državna jamstva u Cipru, Portugalu, Španjolskoj i Italiji porasla su od 2010. do 2013. za više od 5\% BDPa, uglavnom zbog novih izdanja jamstava financijskim institucijama. S druge strane, iznos jamstava $u$ Velikoj Britaniji, Austriji, a posebno Irskoj znatno se smanjio, uglavnom zbog isteka interventnih mjera za spašavanje financijskog sustava uvedenih tijekom krize. U Ujedinjenom Kraljevstvu, jamstva izdana u okviru programa likvidnosti prestala su postojati 2013. Austrijska Clearingbank, koja je služila kao posrednik na međubankarskom tržištu kroz posuđivanje sredstava (uz potporu državnih jamstava) te kreditiranje kreditnih institucija i osiguravajućih društava, ugašena je 20II. Irska NAMA je osnovana s ciljem rješavanja problema smanjenja vrijednosti imovine $\mathrm{u}$ bankarskom sustavu. Imovina (prvenstveno krediti za kupnju zemlje i razvojni krediti) prebačeni su iz banaka NAMA-i s ciljem jačanja bilanci banaka i smanjenja neizvjesnosti povezanih s lošom aktivom (imovinom). Osim toga, Eligible Liabilities Guarantee (ELG) shema uvedena je kako bi se institucijama koje sudjeluju (uglavnom sistemski važnim i solventnim kreditnim institucijama iz Irske) omogućio pristup srednjoročnom financiranju uz državno jamstvo (s rokom dospijeća do pet godina). Budući da je ELG shema ukinuta, a zadatak NAMA-e je bio da svede bilancu na nulu čim to bude komercijalno izvedivo, državna jamstva $u$ Irskoj su se smanjila od 2010. do 2013. za gotovo 65\% BDP-a.

\section{GRAFIKON 3.}

Ukupan dug (bruto dug uvećan za jamstva) opće države zemalja članica EU-a u 2013. (u \% BDP-a)

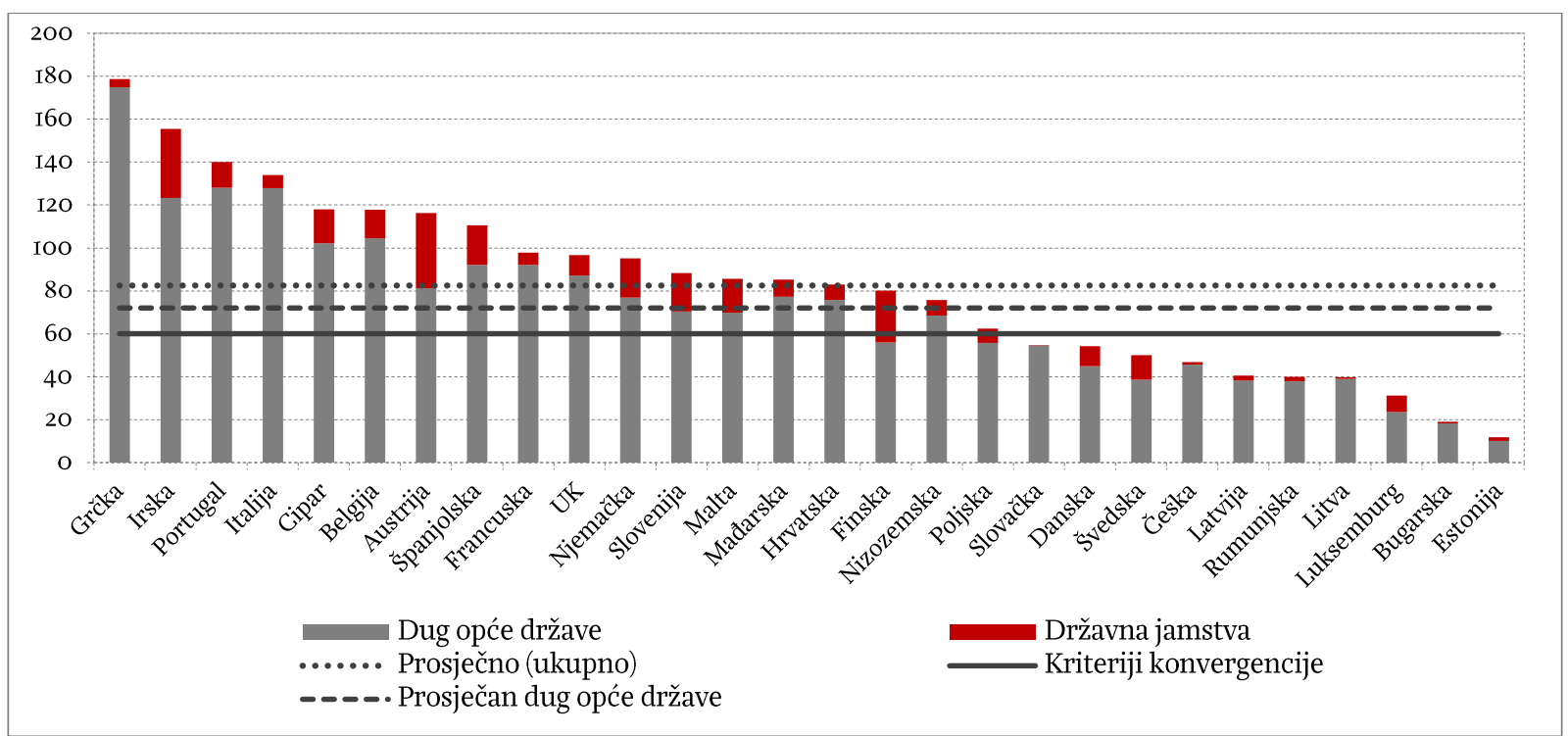

Izvor: Eurostat.

Za dobivanje jasnog uvida u značaj državnih jamstava u zemljama članicama EU-a, korisno je također usporediti veličinu državnih jamstava s veličinom javnog duga. Udio duga opće države u BDP-u u 2013. bio je najniži u Estoniji (Io\%), a najviši u Grčkoj (175\%) (grafikon 3). Omjer duga i BDP-a u Hrvatskoj je iznosio $76 \%$, što je iznad prosjeka EU-a od 72\%. Uključivanjem državnih jamstava, ukupna slika relativno visoke zaduženosti javnog sektora, ne mijenja mnogo: osim Grčke, Irske, Portugala, Italije Cipra i Belgije, u još dvije zemlje - Austriji i Španjolskoj - bi ukupan državni dug prelazio Ioo\% BDP-a, a u još tri - Francuskoj, Ujedinjenom Kraljevstvu i Njemačkoj - bio bi blizu te vrijednosti. Samo Io od 28 
zemalja bi udovoljavalo referentnoj vrijednosti od 60\% BDP-a sukladno kriteriju iz Maastrichta, dok isključivanjem jamstava taj kriterij ispunjava 12 zemalja.

\section{VELIČINA I STRUKTURA DRŽAVNIH JAMSTAVA U HRVATSKOJ}

U Hrvatskoj se izdaju dvije vrste jamstava - financijska i činidbena. Od 1995. Vlada i Ministarstvo financija izdaju samo financijska jamstva, a od 1998. se službeno pojavljuju i činidbena jamstva (Bajo et al., 20II.). Kod financijskih jamstava, država jamči za financijske obveze dužnika ukoliko je dužnik u nemogućnosti podmirenja istih po njihovom dospijeću. S druge strane, činidbena jamstva se izdaju na temelju zaloga pokretnina, a kojima se jamči izvršenje ugovora o isporuci/povratu dobara ili usluga. Grafikon 4 prikazuje iznose financijskih i činidbenih jamstava izdanih u razdoblju od 2009. do prve polovice 2015 .

\section{GRAFIKON 4.}

Financijska i činidbena jamstva izdana od 2009. do prve polovice 2015. (u mlrd. kuna)

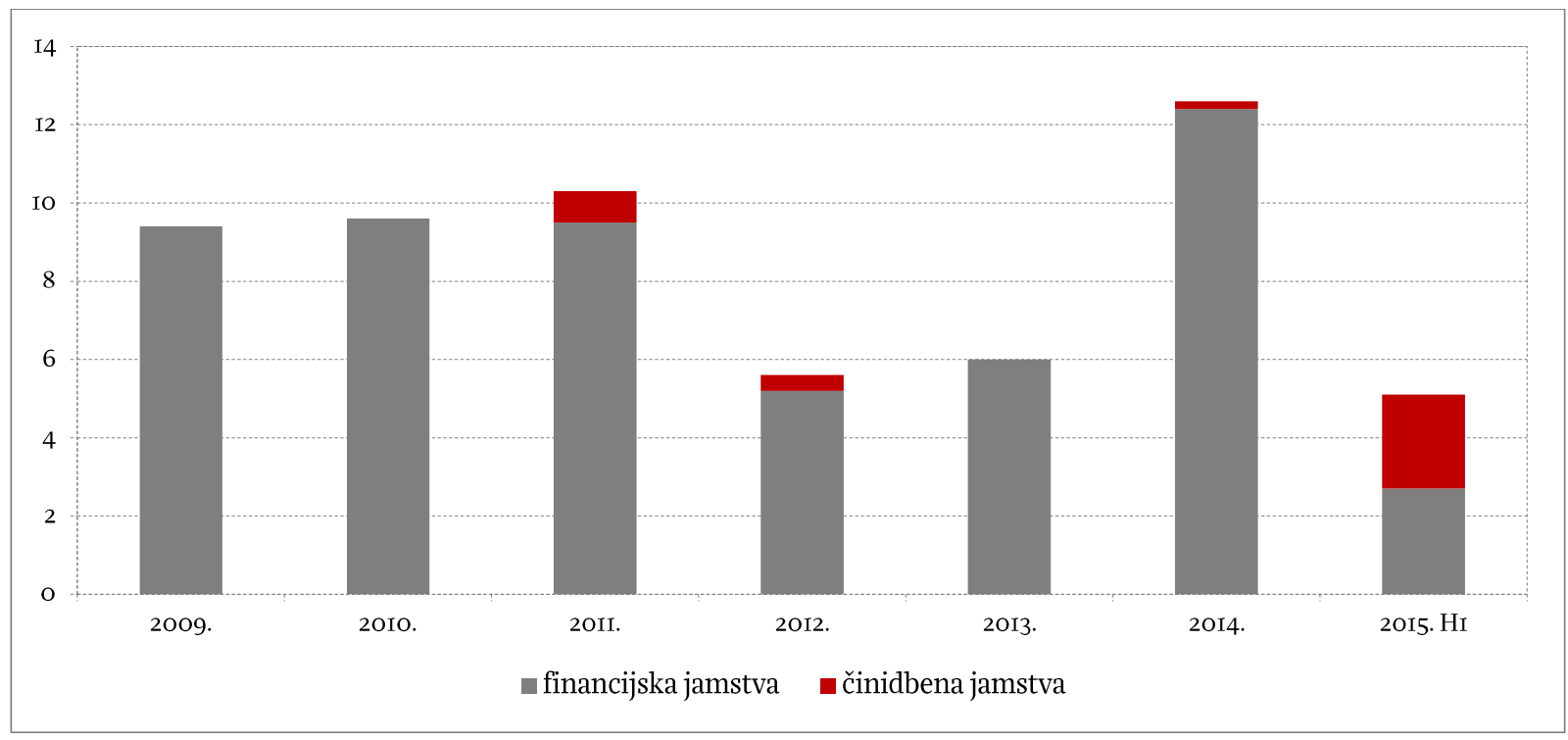

Izvor: autori na temelju Ministarstvo financija (20O9., 2OIO., 2OII., 2OI2., 2OI3., 2OI4a. i 2OI5a.).

Ukupan iznos izdanih jamstava se kreće od 5,6 mlrd. kuna u 2012. do I2,6 mlrd. kuna u 2014. U promatranom razdoblju prevladavaju financijska jamstava, dok se značajan iznos činidbenih jamstava pojavljuje tek u prvoj polovici 2015. u sektoru brodogradnje, koji nakon nekog vremena opet postaje značajan (ako ne i dominantan) korisnik državnih jamstava.

Zakonom o izvršavanju državnog proračuna, koji se donosi za svaku proračunsku godinu, propisuje se planirana godišnja vrijednost novih državnih jamstava, jednako kao i uvjeti za njihovo izdavanje. Grafikon 5, koji prikazuje usporedbu planiranih i izdanih financijskih jamstava u svakoj promatranoj godini, otkriva da je tijekom cijelog promatranog razdoblja izdano više financijskih jamstava nego li je to utvrđeno zakonima o izvršavanju državnog proračuna. Razlog tome je što jamstva izdana na temelju odluka Sabora, a koja imaju veliki udio u ukupno izdanim jamstvima, ne ulaze u godišnje ograničenje izdavanja državnih jamstava (Bajo i Petrušić, 2014.). Ograničenjima podliježu samo jamstva izdana uz suglasnost Vlade. U 2012. i 2013., jaz između planiranih i izdanih jamstava je nešto manji zbog manje aktivnosti izdavanja državnih jamstava odlukama Sabora. Međutim, trend je opet promijenjen u 20I4., kada je iznos izdanih jamstava više nego dvostruko veći od maksimalnog iznosa propisanog odredbama 
Zakona o izvršavanju državnog proračuna.

\section{GRAFIKON 5.}

Planirana i izdana financijska jamstva od 2009. do prve polovice 20I5. (u mlrd. kuna)



Izvor: autori na temelju Ministarstvo financija (2009., 20IO., 20II., 20I2., 20I3., 20I4a. i 20I5a.).

\section{GRAFIKON 6.}

Izdana domaća i inozemna financijska jamstva od 2009. do prve polovice 2015. ( u mlrd. kuna)

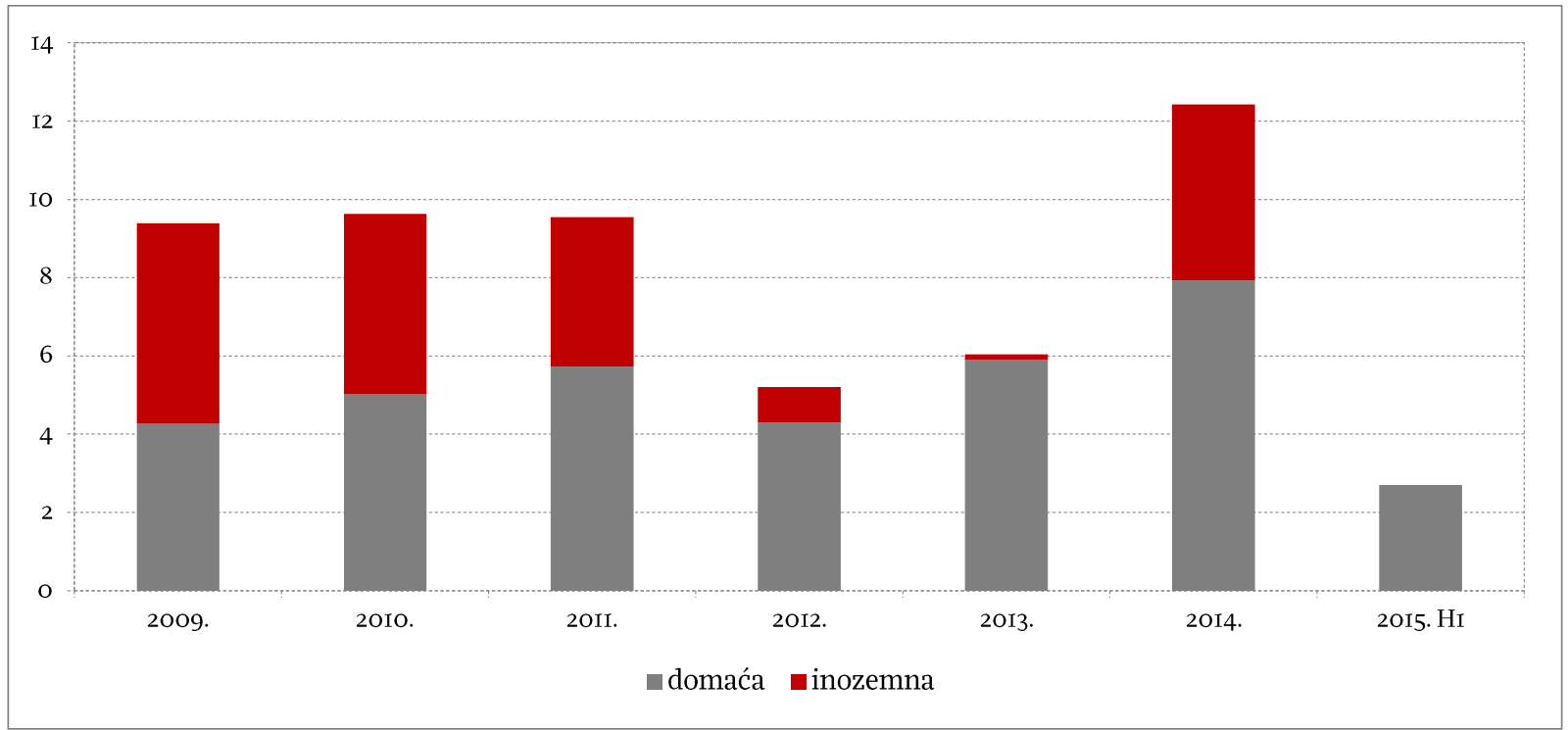

Izvor: autori na temelju Ministarstvo financija (2009., 20IO., 2ОII., 20I2., 20I3., 20I4a. i 20I5a.).

Nekoliko drugih prikaza (koji slijede u nastavku) pružaju zanimljive informacije vezane uz strukturu državnih jamstava, i način na koji su se s vremenom izdavala.

Prema strukturi financijskih jamstava, iz grafikona 6 vidi se trend povećanja udjela izdanih jamstava za zaduživanje kod domaćih financijskih institucija u cijelom promatranom razdoblju. U 2013., udio takvih jamstava iznosi čak 98\% ukupno izdanih financijskih jamstava. Međutim, takvo povećanje nije rezultat većeg oslanjanja javnih poduzeća na zaduživanje kod domaćih banaka, već značajnog smanjenja zaduživanja kod stranih banaka, a time i jamstava za inozemno zaduživanje. Taj trend se mijenja u 2oI4., 
kada je izdano 4,5 mlrd. kuna jamstava za zaduživanje Hrvatskih autocesta kod inozemnih financijskih institucija.

Što se tiče valutne strukture zajmova s državnim financijskim jamstvom u promatranom razdoblju, dominiraju jamstva odobrena u eurima (grafikon 7). Jamstva izdana za zajmove denominirane u kunama kontinuirano rastu između 2009. i 2014., ali su u prvoj polovici 2015. potpuno iščezla.

\section{GRAFIKON 7.}

Valutna struktura izdanih financijskih jamstava od 2009. do prve polovice 2015. (u mlrd. kuna)

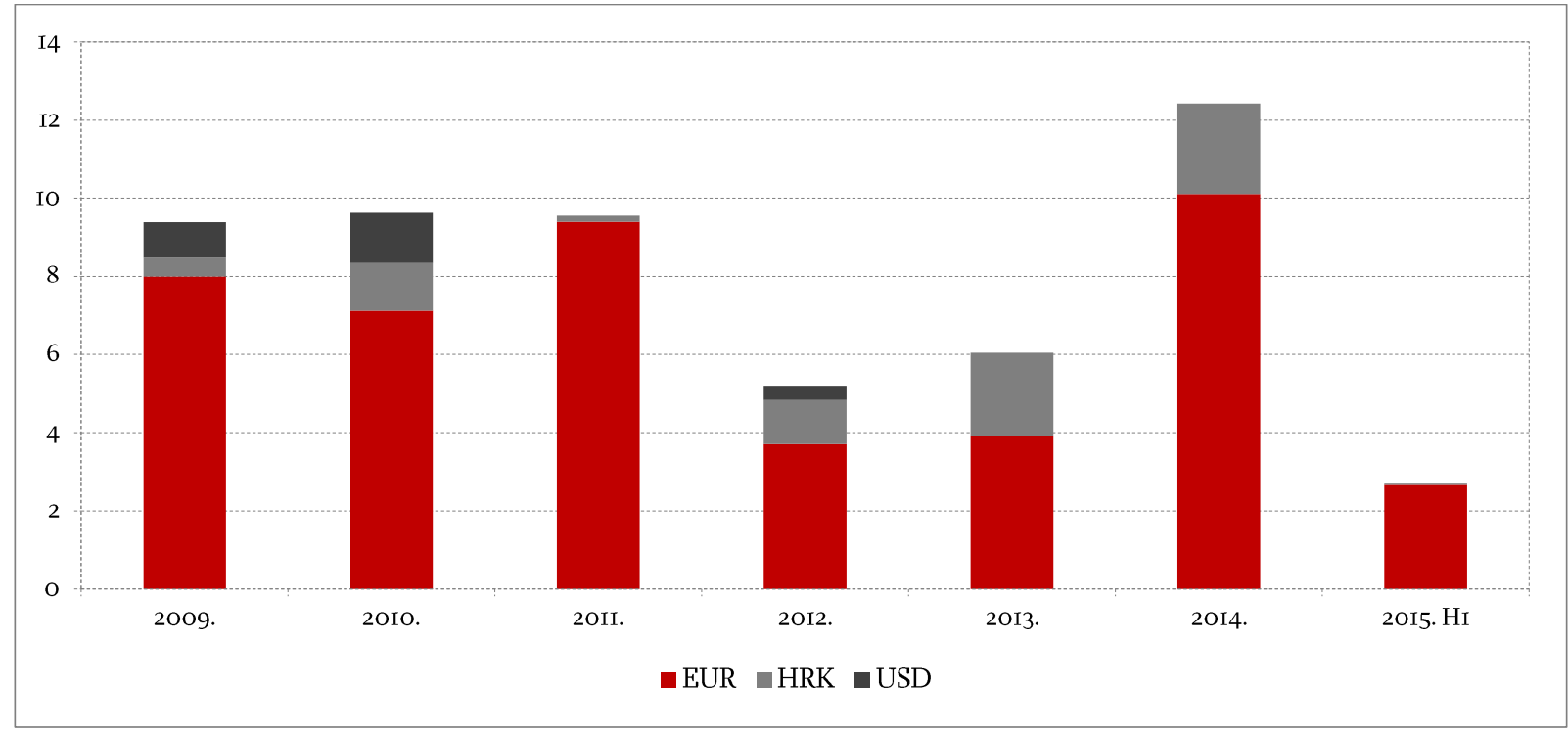

Izvor: autori na temelju Ministarstvo financija (2009., 20IO., 20II., 20I2., 20I3., 20I4a. i 20I5a.).

\section{GRAFIKON 8.}

Struktura izdanih financijskih jamstava po vrsti vjerovnika od 2009. do prve polovice 2015. (u mlrd. kuna)



Izvor: autori na temelju Ministarstvo financija (2009., 20IO., 2OII., 2OI2., 2OI3., 2OI4a. i 20I5a.).

Većina državnih jamstava izdaje se za zajmove dobivene od domaćih poslovnih banaka (grafikon 8). Udio financijskih jamstava izdanih u korist inozemnih poslovnih banaka značajno je smanjen između 2010. i 20I3., ali u 20I4. doseže dosad najvišu razinu. To je ponajviše zbog jamstva danog Deutsche Bank 
London za zaduženje Hrvatskih autocesta za refinanciranje postojećih dugova. U razdoblju od 20o9. do 20II., državna jamstva se izdaju također i za zaduživanje kod međunarodnih financijskih institucija (EBRD, IBRD i EIB), ponajviše za infrastrukturne projekte (autoceste, ceste i luke). U 2OI4., jamstva se izdaju i u korist HBOR-a u iznosu od o,8 mlrd. kuna, a u svrhu financiranja kupnje vlakova Hrvatskih željeznica putničkog prijevoza.

U razdoblju od 2009. do 2013., financijska jamstva su se uglavnom izdavala sektoru prometa, ali i sektoru prerađivačke industrije (grafikon 9). U sektoru prometa, jamstva su se najviše izdavala u sklopu infrastrukturnih projekata za zaduživanje Hrvatskih cesta, Hrvatskih autocesta, Hrvatskih željeznica te za zaduživanje lučkih uprava (Rijeka, Split i Zadar). U 2009., a značajnije u 2010., velik je dio financijskih jamstava izdan poduzećima u sektoru prerađivačke industrije i to najvećim dijelom za zaduženje brodogradilišta. ${ }^{4}$ Kako su brodogradilišta privatizirana i restrukturirana, od 20II. godine, država više nije imala potrebe izdavati jamstva za njihova zaduživanja. Međutim, financijske poteškoće cestovnih poduzeća su se intenzivirale pa su gotovo sva jamstva izdana od 20II. pokrivala kredite poduzećima iz sektora prometa. Ukratko, prije 20Io. državna jamstva se izdaju isključivo za podupiranje neprofitabilne industrije brodogradnje, a od 20II. za potrebe neprofitabilnih cestovnih društava.

\section{GRAFIKON 9.}

Struktura i vrijednost izdanih financijskih jamstava po sektorima od 2009. do prve polovice 2015. (u mlrd. kuna)

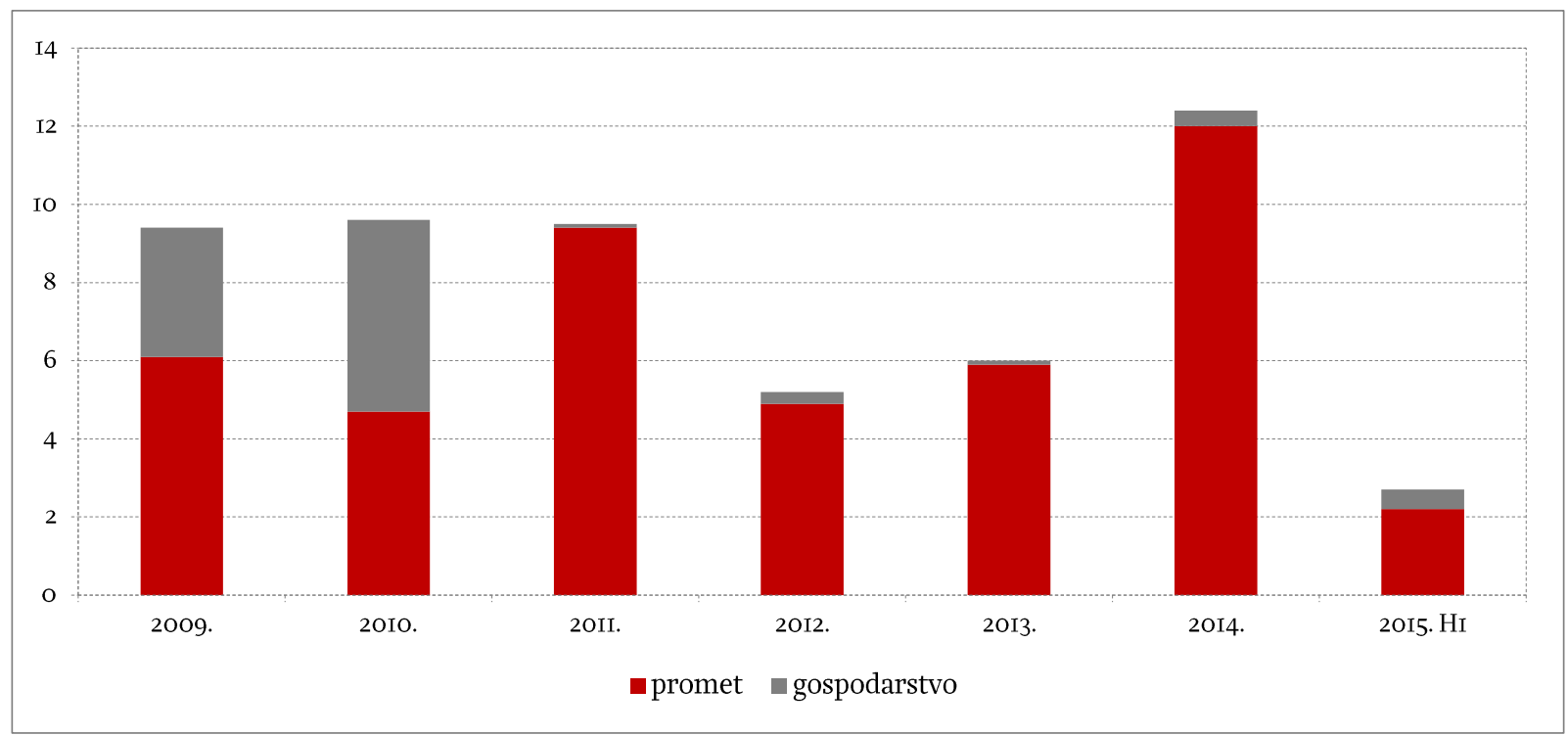

Izvor: autori na temelju Ministarstvo financija (2009., 20IO., 20II., 20I2., 20I3., 20I4a. i 20I5a.).

\section{FISKALNE POSLJEDIGE DRŽAVNIH JAMSTAVA}

Jedan dio zajmova za koje država jamči godišnje dolazi na naplatu, tj. jamstva se protestiraju i postaju izravan dug države. Nakon protesta, Vlada i Ministarstvo financija ulažu napore u povrat dijela iznosa protestiranih jamstava. Nažalost, povrati u državni proračun su slabi što znači da su izvorni dužnici suočeni s dugoročnim financijskim problemima te nisu u stanju podmirivati obveze po kreditima za koje jamči država.

4 Za detaljnije pojašnjenje fiskalnih rizika koji su nastali kao rezultat jamstava izdanih za sektor brodogradnje, pogledati Bajo i Primorac (20II.). 
Najveći dio jamstava je protestiran u 2009., 2010. i 20II., ponajviše u sektoru brodogradnje (u 2009. čak I,9 mlrd. kuna), ali i u sektoru prometa, turizma i poljoprivrede. U 20I2. su protestirana jamstva čak 65,4\% manja u odnosu na 20II., primarno zbog toga što se plaćanje obveza za kredite brodogradilišta koji su bili osigurani državnim jamstvima od ožujka 2012. evidentira u okviru rashoda za otplatu glavnica i kamata, a ne kao povlačenje sredstava iz jamstvene pričuve. Ta promjena je uzrokovana administrativnim manevrom kojim je država $u$ 20II. pretvorila potencijalne obveze sektora brodogradnje (II,3 mlrd. kuna) u izravni javni dug (Bajo i Primorac, 20IIa).

\section{GRAFIKON IO.}

Protestirana financijska jamstva po sektorima od 2009. do prve polovice 2015. (u mlrd. kuna)

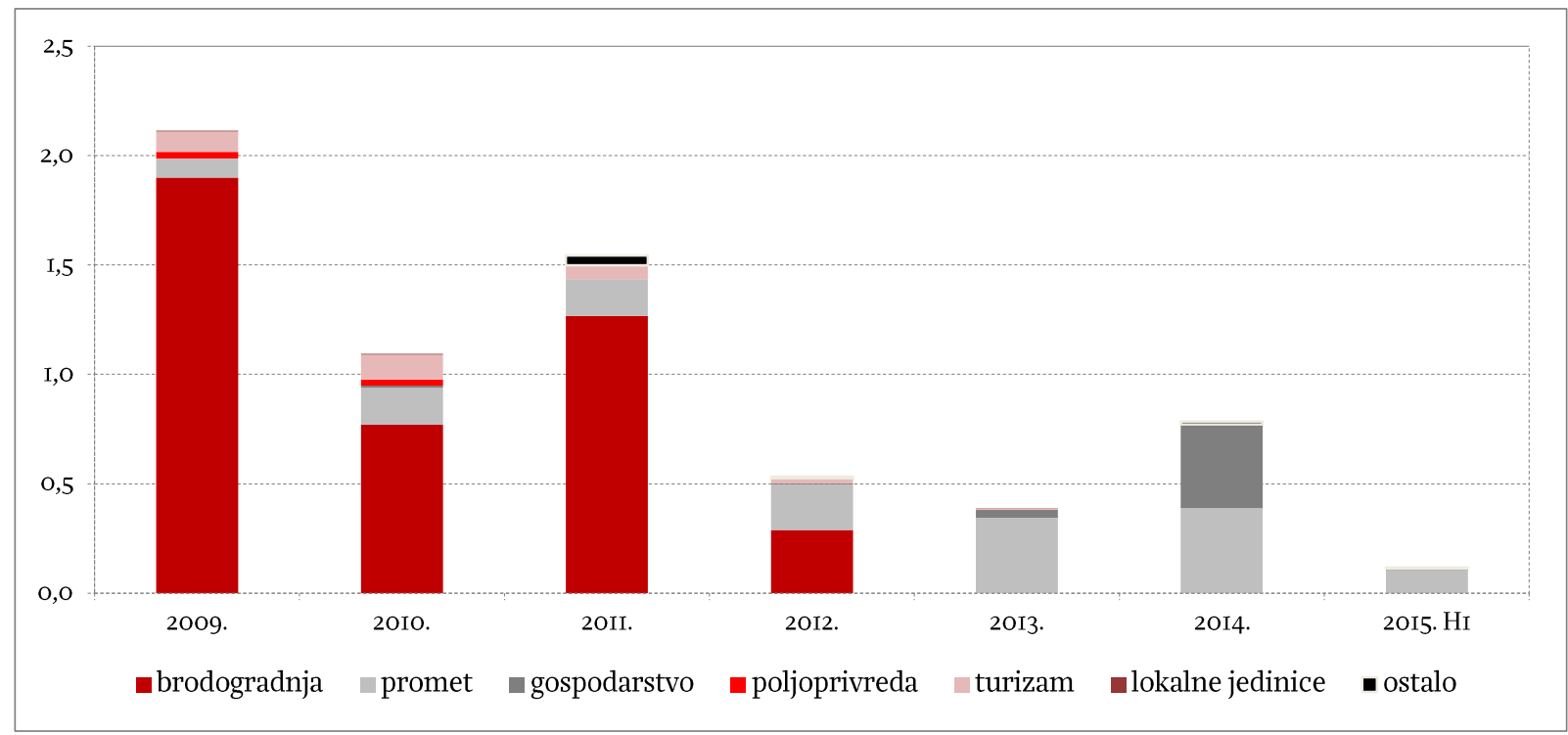

Izvor: autori na temelju Ministarstvo financija (2009., 20IO., 20II., 20I2., 20I3., 20I4a. i 20I5a.).

\section{GRAFIKONII.}

Protestirana jamstva i povrati u državni proračun od 2009. do prve polovice 2015. (u mlrd. kuna)



Izvor: autori na temelju Ministarstvo financija (2009., 20IO., 20II., 20I2., 20I3., 20I4a. i 20I5a.). 
U 2009. i 20IO., ukupno protestirana financijska jamstva su daleko veća nego povrati u proračun na ime protestiranih jamstava. Izvorni dužnici su izravnom uplatom ili na neki drugi način vratili tek I\% iznosa protestiranih jamstava $u$ navedenim godinama. Ipak, u 20II. se situacija neznatno popravila. Uz izravne uplate u državni proračun od samo 26 mil. kuna, država je naplatila potraživanja za isplaćena jamstva stjecanjem udjela u trgovačkom društvu u iznosu od 257 mil. kuna te stjecanjem nekretnine u iznosu od 25 mil. kuna.

Od 2012., stanje se korjenito mijenja. Povrati na ime protestiranih financijskih jamstava u 2012. su gotovo dvostruko veći od ukupno protestiranih jamstava. To je rezultat pretvaranja potraživanja po protestiranim jamstvima u udjele u vlasništvu Croatia Airlinesa d.d. u iznosu od gotovo 900 mil. kuna te stjecanja nekretnine dužnika u iznosu od 3 mil. kuna. Na isti način je, u prvoj polovici 2015., država stekla udjele u HŽ Cargo u iznosu od 454 mil. kuna. Takve operacije su zapravo način skrivenog financiranja kroz povećanje vlasničke glavnice, pri čemu je Republika Hrvatska već jedini dioničar (drži IOO\% udjela). Stoga, u takvim operacijama nema previše ekonomske logike - to su, u stvari, državne potpore s odgođenim učincima i drugačijim računovodstvenim tretmanom.

\section{TABLICA I.}

Jamstvena pričuva i financijska jamstva od 2009. do prve polovice 2015.

\begin{tabular}{|c|c|c|c|c|c|c|}
\hline Godina & $\begin{array}{c}\text { Jamstvena } \\
\text { pričuva } \\
\text { (mlrd. kuna) }\end{array}$ & $\begin{array}{l}\text { Protestirana } \\
\text { jamstva } \\
\text { (mlrd. kuna) }\end{array}$ & $\begin{array}{l}\text { Potencijalno } \\
\text { dospijeće } \\
\text { (mlrd. kuna) }\end{array}$ & $\begin{array}{l}\text { Pričuva/ } \\
\text { dospijeće } \\
(\%)\end{array}$ & $\begin{array}{c}\text { Pričuva/ } \\
\text { protestirano } \\
(\%)\end{array}$ & $\begin{array}{c}\text { Protest/ } \\
\text { dospijeće } \\
(\%)\end{array}$ \\
\hline 2009. & 0,7 & $2, I$ & 3,8 & I8 & 32 & 56 \\
\hline 2010. & $\mathrm{I}, \mathrm{O}$ & $\mathrm{I}, \mathrm{I}$ & 3,2 & $3 I$ & 9I & 34 \\
\hline 2 OII. & $\mathrm{I}, \mathrm{O}$ & $\mathrm{I}, 5$ & 7,7 & I3 & 65 & 20 \\
\hline $2 \mathrm{OI} 2$. & $\mathrm{I}, \mathrm{O}$ & 0,5 & $5, \mathrm{I}$ & 20 & I87 & IO \\
\hline 2013. & 0,5 & 0,4 & 4,3 & II & I2I & 9 \\
\hline $20 I 4$. & 0,8 & 0,8 & 5,6 & I5 & IO6 & I4 \\
\hline 2015 PI. & 0,5 & $\mathrm{O}, \mathrm{I}$ & 4,5 & $\mathrm{I} 2$ & 464 & 3 \\
\hline
\end{tabular}

Izvor: autori na temelju Ministarstvo financija (2009., 20IO., 2OII., 20I2., 20I3., 20I4a. i 20I5a.).

Između 2009. i 20II. sredstva jamstvene pričuve nisu bila dostatna za otplate protestiranih jamstava te se razlika trebala osigurati iz dodatnih izvora. U preostalom razdoblju, nakon pokrića protestiranih jamstava, u jamstvenoj je pričuvi ostalo još i neiskorištenih sredstava. Razlog tome je uglavnom promjena $u$ evidenciji kreditnih obveza brodogradilišta osiguranih državnim jamstvima 20II. Kroz cijelo promatrano razdoblje, sredstva jamstvene pričuve bila su dostatna za pokriće manje od 20\% aktivnih jamstava s potencijalnim dospijećem u pojedinoj godini (uz iznimku 20IO. - 31\%). Omjer protestiranih i aktivnih jamstava postupno se smanjio s prilično visokih $56 \%$ u 2009. na samo $3 \%$ u prvoj polovici 2015. To je najvećim dijelom posljedica promjena u statistici nacionalnih računa i evidenciji jamstava. 


\section{GRAFIKONI2.}

Vrijednost i rok potencijalnog dospijeća financijskih jamstava aktivnih na kraju prve polovice 2015. (u mlrd. kuna)

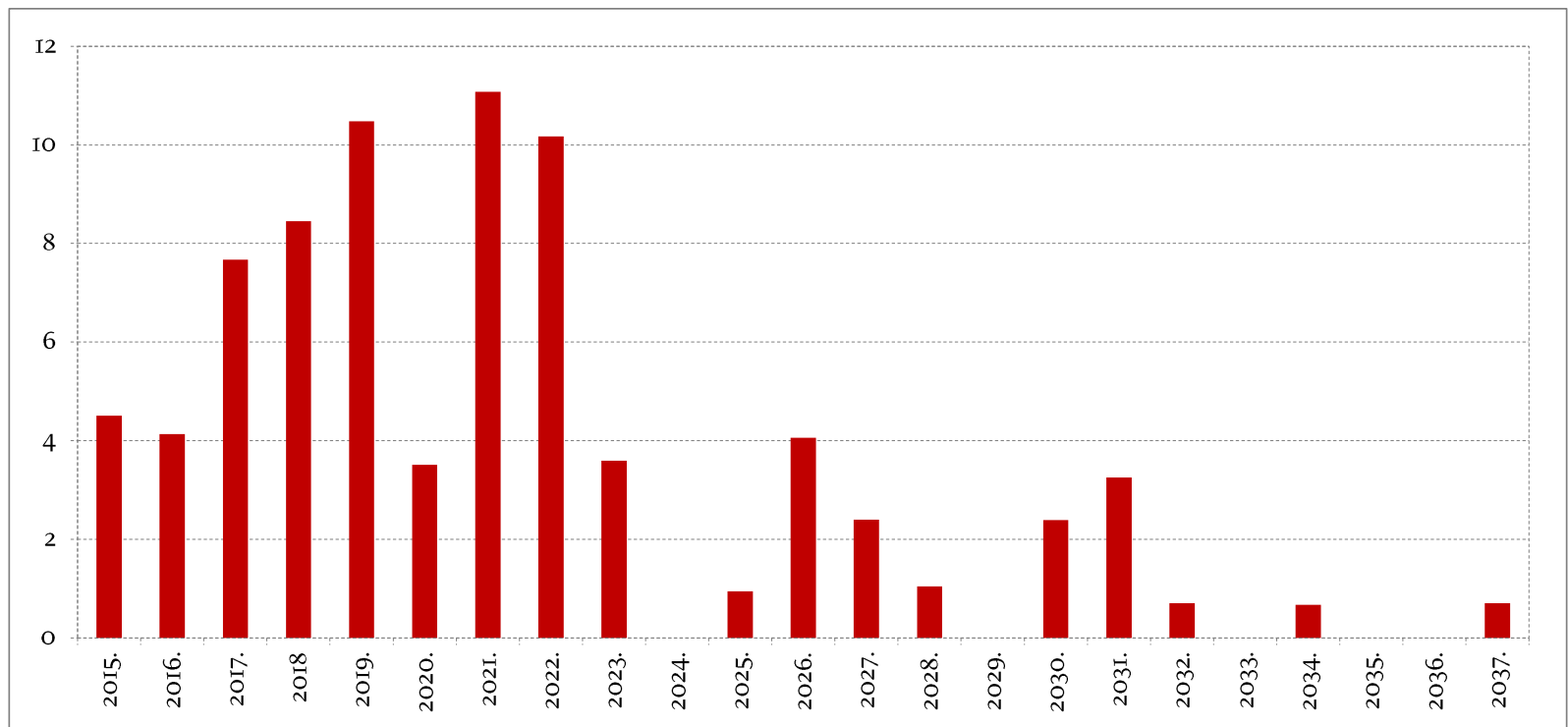

Izvor: autori na temelju Ministarstvo financija (2009., 20IO., 20II., 20I2., 20I3., 20I4a. i 20I5a.).

Korisnici državnih jamstava stvorili su obveze za otplate glavnice i kamata duga čak do 2037. Iznosi i vrijeme potencijalnog dospijeća financijskih jamstava razlikuju se po godinama. U 2015. i 2016. ističe rok dospijeća kreditima koji su pokriveni državnim jamstvima u iznosu od oko 8 mlrd. kuna. Od 2017. do 2019. - te također u 2022. - državni proračun bit će pod velikim pritiskom zbog potencijalnog protesta izdanih financijskih jamstava i njihovog pretvaranja u izravan javni dug.

Neizvjesnost koja je stvorena izdavanjem jamstava značajan je izvor rizika iz perspektive održivosti javnog duga. Ukoliko iznos protestiranih jamstava prijeđe očekivanu razinu, to bi moglo narušiti održivost javnog duga, povećati vjerojatnost fiskalnih problema te u konačnici uzrokovati krizu (IMF, 2005.).

Iako se $\mathrm{u}$ javnosti često krivo interpretira, povećanje vrijednosti javnog duga u Hrvatskoj u posljednjih nekoliko godina ne može se pripisati isključivo povećanju neto zaduživanja države, već - u značajnoj mjeri - "statističkom povećanju” zbog promjena u metodološkom okviru statistike javnog duga. Te promjene se uglavnom odnose na povećanje obuhvata javnog duga kroz povećanje obuhvata opće države. Drugim riječima, promjene metodološkog okvira usmjerene su na uključivanje institucija koje su formalno izvan opće države u obuhvat opće države, ukoliko postoji vjerojatnost da će opća država preuzeti njihove obveze. Uključivanje obveza takvih institucija u izravni javni dug smanjuje iznos državnih jamstava odobrenih tim institucijama kako bi se u statistici duga izbjeglo dvostruko uključivanje istog iznosa (prvo kao izravna, a zatim i kao neizravna obveza).

Od 2009. do 2013. udio javnog duga u BDP-u u Hrvatskoj povećao se za 73\%. Unatoč tome, tranzicija metodološkog okvira - s GFS (engl. Government Finance Statistics) na ESA (engl. European System of National and Regional Accounts) 95 te konačno na ESA 2010 - stvorila je u javnosti percepciju da se udio javnog duga u BDP-u u 2013. udvostručio u odnosu na 2009. (76\% BDP-a u 2013. prema ESA 2010 u odnosu na $36 \%$ BDP-a u 2009. prema GFS). 
TABLICA 2.

Dug opće države i državna jamstva od 2009. do 20I3. prema različitim metodologijama (u mlrd. kuna i\% BDP-a)

\begin{tabular}{|c|c|c|c|c|c|c|c|c|c|c|}
\hline \multirow{2}{*}{ Metodologija } & \multicolumn{2}{|c|}{2009.} & \multicolumn{2}{|c|}{2010.} & \multicolumn{2}{|c|}{$20 I I}$. & \multicolumn{2}{|c|}{2012.} & \multicolumn{2}{|c|}{2013.} \\
\hline & $\begin{array}{l}\text { Mlrd. } \\
\text { HRK }\end{array}$ & $\begin{array}{c}\% \\
\text { BDP-a }\end{array}$ & $\begin{array}{c}\text { Mlrd. } \\
\text { HRK }\end{array}$ & $\begin{array}{c}\% \\
\text { BDP-a }\end{array}$ & $\begin{array}{c}\text { Mlrd. } \\
\text { HRK }\end{array}$ & $\begin{array}{c}\% \\
\text { BDP-a }\end{array}$ & $\begin{array}{c}\text { Mlrd. } \\
\text { HRK }\end{array}$ & $\begin{array}{c}\% \\
\text { BDP-a }\end{array}$ & $\begin{array}{c}\text { Mlrd. } \\
\text { HRK }\end{array}$ & $\begin{array}{c}\% \\
\text { BDP-a }\end{array}$ \\
\hline $\mathrm{BDP}(\mathrm{ESA} 2 \mathrm{OIO})^{(\mathrm{c})}$ & 33I,O & IOO & 328,0 & IOO & 332,6 & IOO & 330,5 & IOO & 33O,I & IOO \\
\hline \multicolumn{11}{|c|}{ Dug opće države } \\
\hline GFS 200I ${ }^{(a)}$ & $\mathrm{II} 7,7$ & 36 & $\mathrm{I} 38, \mathrm{O}$ & 42 & I56,O & 47 & $\mathrm{I} 77,3$ & 54 & $\mathrm{n} / \mathrm{a}$ & $\mathrm{n} / \mathrm{a}$ \\
\hline ESA $95^{(\mathrm{b})}$ & $\mathrm{I} 2 \mathrm{O}, 8$ & 36 & $\mathrm{I} 45,7$ & 44 & $\mathrm{I} 7 \mathrm{O}, 9$ & $5 \mathrm{I}$ & I83,7 & 56 & $22 \mathrm{O}, 2$ & 67 \\
\hline ESA 2OIO ${ }^{(\mathrm{c})}$ & I58,9 & 48 & I86,9 & 57 & 2II,9 & 64 & 228,8 & 69 & 266,I & $8 \mathrm{I}$ \\
\hline ESA 2OIO-95 & $38, \mathrm{I}$ & I2 & $4 \mathrm{I}, 2$ & I3 & $4 \mathrm{I}, \mathrm{O}$ & $\mathrm{I} 2$ & $45, \mathrm{I}$ & I4 & 45,9 & $\mathrm{I} 4$ \\
\hline \multicolumn{11}{|c|}{ Državna jamstva } \\
\hline GFS 200I ${ }^{(a)}$ & 50,9 & I5 & 59,4 & I8 & 59,9 & I8 & $55, \mathrm{I}$ & I7 & $\mathrm{n} / \mathrm{a}$ & $\mathrm{n} / \mathrm{a}$ \\
\hline ESA 95(b) & 51,9 & I6 & 56,9 & I7 & $5 \mathrm{I}, \mathrm{O}$ & I5 & 54,3 & I6 & 53,7 & I6 \\
\hline ESA 20IO(c) & $\mathrm{I} 3, \mathrm{I}$ & 4 & $\mathrm{I} 4,9$ & 4 & 8,4 & 3 & 8,6 & 2 & 8,0 & 2 \\
\hline ESA 2OIO-95 & $-38,8$ & $-\mathrm{I} 2$ & $-42,0$ & $-\mathrm{I} 3$ & $-42,6$ & $-\mathrm{I} 2$ & $-45,7$ & $-\mathrm{I} 4$ & $-45,7$ & $-\mathrm{I} 4$ \\
\hline
\end{tabular}

Izvor: (a) MFIN (2OI4.); (b) HNB (2OI4.); ${ }^{(c)} \mathrm{HNB}$ (2OI5.) i MFIN (2OI5.).

Od rujna 20I4. sve zemlje članice EU-a obvezne su primjenjivati ESA 20IO, koji predstavlja europsku verziju UN-ovog metodološkog okvira Sustava nacionalnih računa (engl. System of National Accounts SNA 2008). Zbog novog načina evidentiranja različitih dijelova nacionalne ekonomije, značajno se izmijenio obuhvat ekonomskih sektora. Uz promjene u izračunu BDP-a, promjene su se također odrazile i na obuhvat i veličinu deficita i duga opće države.

Glavni razlog promjene razine jamstava i duga opće države prelaskom s ESA 95 na ESA 2010 bila je reklasifikacija obveza društava Hrvatske autoceste i Autocesta Rijeka-Zagreb, Hrvatske željeznice infrastruktura, Hrvatske radiotelevizije, kao i Hrvatske banke za obnovu i razvitak, Državne agencija za osiguranje štednih uloga i sanaciju banaka te Hrvatskog operatora tržišta energije u sektor konsolidirane središnje države (DZS, 2015.). Time je retroaktivno povećana razina duga opće države, i posljedično smanjen iznos državnih jamstava u cjelokupnom razdoblju. U 2013., razlika između iznosa jamstava prema staroj (ESA 95) i novoj(ESA 20Io) metodologiji bila je gotovo $46 \mathrm{mlrd}$. kuna. U relativnim okvirima, iznos jamstava prema ESA 95 bio je I6\% BDP-a, a prema ESA 2010 svega 2\% BDP-a. Istovremeno se razina duga opće države iskazana prema ove dvije metodologije razlikovala za gotovo isti iznos - prema ESA 95 bila je 67\% BDP-a, a prema ESA 20I0 81\% BDP-a. Ukupni javni dug (dug opće države uvećan za jamstva) iznosio je 83\% BDP-a u oba slučaja, samo je struktura ukupnog duga (izravni vs. neizravni) bila drugačija. To potvrđuje činjenicu da je porast duga opće države u 2013. bio - u većom mjeri - kompenziran odgovarajućim smanjenjem iznosa jamstava, tj. neizravni dug se preobrazio $u$ izravni (zbog metodoloških promjena) što je prouzročilo "statističko povećanje” javnog duga. Sličan zaključak može se donijeti i za ostatak promatranog razdoblja (vidi tablicu 2 i usporedi razliku ESA 2OIO95 za dug opće države i državna jamstva). 


\section{ZAKLJUČAK}

Državna jamstva su značajan izvor fiskalnih rizika i prijete stabilnosti javnih financija kako u razvijenim zemljama, tako i u zemljama u razvoju. To ukazuje na potrebu provedbe primjerene politike izdavanja i upravljanja jamstvima. Dobre prakse u pogledu upravljanja potencijalnim obvezama uključuju oblikovanje sveobuhvatnih i transparentnih baza podataka, uvođenje određenih ograničenja u pogledu izloženosti fiskalnim rizicima, osnivanje fonda pričuve za potencijalne obveze te uspostavljanje zasebnog zakonodavnog i institucionalnog okvira za upravljanje fiskalnim rizicima.

Financijska kriza teško je pogodila gospodarstva zemalja članica EU-a i destabilizirala njihove financijske sustave. S ciljem očuvanja financijske stabilnosti, te zemlje su provodile različite interventne mjere često uz potporu državnih jamstava. Zbog toga je iznos izdanih jamstava u pojedinim zemljama (primjerice u Irskoj, Austriji, Finskoj i Sloveniji) dosegnuo zabrinjavajuće razine. S druge strane, Slovačka, Češka, Bugarska i baltičke zemlje imale su prilično nisku razinu jamstava. Iako je iznos jamstava u postotku BDP-a u Hrvatskoj u odnosu na druge zemlje članice bio nizak, treba istaknuti da su se državna jamstva u Hrvatskoj pokazala kao značajan izvor rizika. Naime, usvajanje šireg europskog okvira nacionalne statistike (ESA 20IO) pružilo je sveobuhvatniju sliku državnih financija pretvaranjem oko I4\% BDP-a neizravnih obveza (jamstava) u izravne (dug opće države). Stoga ispodprosječna razina jamstava u Hrvatskoj nije rezultat razborite (restriktivne) politike izdavanja jamstava, već činjenice da je veći dio izdanih jamstava kvalificirao za konverziju u izravan dug opće države, dok je tek manji dio ostao u domeni potencijalnih obveza.

U Hrvatskoj se pojavljuju dvije vrste jamstava - financijska i činidbena. Može ih odobriti Vlada ili Sabor. Hrvatska je uglavnom izdavala financijska jamstva i to najčešće u iznosu većem od planiranog. Jamstva su se većinom izdavala za zaduživanja na domaćem tržištu denominirana u eurima. Strukturom vjerovnika kontinuirano dominiraju domaće poslovne banke, pri čemu se struktura dužnika u promatranom razdoblju značajno izmijenila. Udio sektora prometa povećao se zbog restrukturiranja i privatizacije brodogradilišta, uslijed čega je smanjen udio jamstava u korist prerađivačke industrije. U strukturi protestiranih jamstava, najznačajnije obveze nastale su između 2009. i 20II. u sektoru brodogradnje, dok se nakon 2012. iznos protestiranih jamstava znatno smanjio. Povrati u proračun na temelju protestiranih jamstava od 2009. do 20II. bili su iznimno niski, no nakon toga iznos povrata čak premašuje iznos protestiranih jamstava. Međutim, ta je pojava uglavnom rezultat pretvaranja državnih potraživanja u udjele u poduzećima što nije osiguralo dodatan priljev sredstava u proračun već je obavljeno na razini računovodstvenih evidencija.

Politika izdavanja državnih jamstava uglavnom javnim poduzećima sa značajnim financijskim problemima rezultirala je neželjenim posljedicama po hrvatski javni dug. Umjesto pružanja potpore zdravim i uspješnim sektorima ekonomije s ciljem poticanja rasta i zapošljavanja, državna jamstva u Hrvatskoj u stvari su korištena za potporu gubitašima (sektoru brodogradnje, prometa i sl.) do njihovog restrukturiranja i privatizacije. Država je znatno ranije trebala pronaći odgovarajuća rješenja za takve sektore $u$ vidu privatizacije ili davanja u koncesije.

Primjereno upravljanje državnim jamstvima može uvelike smanjiti s njima povezane fiskalne rizike. Međutim, preduvjet određivanja kvalitetnih strateških ciljeva je dostupnost pouzdanih informacija o veličini i strukturi državnih jamstava. Administrativni okvir za izdavanje i upravljanje jamstvima također bi trebalo unaprijediti. Zakonodavni okvir mogao bi se poboljšati donošenjem jedinstvenog zakona koji bi regulirao područje javnog duga i fiskalnih rizika. Objedinjavanje svih funkcija povezanih 
s upravljanjem javnim dugom i fiskalnim rizicima u jednoj instituciji (agenciji) bez sumnje bi doprinijelo kvaliteti institucionalnog okvira, koji je trenutno sačinjen od svega nekoliko zaposlenika Ministarstva financija. Primjerena administrativna infrastruktura je nužan uvjet za sastavljanje relevantnih i pouzdanih izvješća kao i donošenje strategija upravljanja javnim dugom i fiskalnim rizicima. 
PRILOG

TABLICA AI.

Ukupna vrijednost državnih jamstava u zemljama članicama EU od 20IO. do 2013. (u \% BDP-a)

\begin{tabular}{|c|c|c|c|c|c|}
\hline & 2010. & 2011. & 2012. & 2013. & Prosjek Io/I3. \\
\hline Belgija & $\mathrm{I} 7, \mathrm{I7}$ & 14,30 & 17,08 & I3,29 & 15,46 \\
\hline Bugarska & $\mathrm{I}, 33$ & $\mathrm{I}, \mathrm{I} 5$ & 0,98 & 0,75 & I,O5 \\
\hline Češka & 0,82 & 0,72 & $\mathrm{I}, \mathrm{IO}$ & I,I9 & 0,96 \\
\hline Danska & 14,62 & $\mathrm{I} 2,77$ & 7,15 & $9, \mathrm{I} 8$ & IO,93 \\
\hline Njemačka & 21,23 & I9,66 & $\mathrm{I} 8,8 \mathrm{I}$ & $\mathrm{I} 8,22$ & 19,48 \\
\hline Estonija & 2,64 & 2,19 & $\mathrm{I}, 95$ & $\mathrm{I}, 7 \mathrm{I}$ & 2,12 \\
\hline Irska & 96,00 & 83,89 & 66,89 & 32,14 & 69,73 \\
\hline Grčka & 3,23 & 3,85 & 3,86 & 3,67 & 3,65 \\
\hline Španjolska & $\mathrm{I} 2,74$ & $\mathrm{I} 4,84$ & 20,68 & $\mathrm{I} 8,4 \mathrm{I}$ & 16,67 \\
\hline Francuska & 6,65 & 5,57 & 4,55 & 5,53 & 5,58 \\
\hline Hrvatska & 8,97 & 6,76 & 7,55 & 7,25 & 7,63 \\
\hline Italija & $\mathrm{O}, 8 \mathrm{I}$ & 3,53 & 6,16 & 6,IO & 4,15 \\
\hline Cipar & 7,47 & $7,8 \mathrm{I}$ & $\mathrm{I} 4,46$ & $\mathrm{I} 5,85$ & $\mathrm{II}, 4 \mathrm{O}$ \\
\hline Latvija & 2,88 & 3,03 & $2,9 \mathrm{I}$ & $2,3 \mathrm{I}$ & 2,78 \\
\hline Litva & $\mathrm{I}, 36$ & 0,99 & 0,84 & 0,82 & $\mathrm{I}, \mathrm{OO}$ \\
\hline Luksemburg & 5,12 & 5,03 & 7,66 & 7,72 & 6,38 \\
\hline Mađarska & 9,48 & 8,82 & 8,74 & 8,03 & 8,77 \\
\hline Malta & II,8O & $\mathrm{I} 2,53$ & $\mathrm{I} 6,52$ & $\mathrm{I} 5,88$ & $\mathrm{I} 4, \mathrm{I} 8$ \\
\hline Nizozemska & IO,77 & 9,95 & 7,95 & 7,22 & 8,97 \\
\hline Austrija & 53,35 & $47, \mathrm{I} 3$ & $4 \mathrm{I}, \mathrm{I} 6$ & $35, \mathrm{OI}$ & $44, I 6$ \\
\hline Poljska & 5,28 & 6,28 & 6,25 & 6,80 & 6,15 \\
\hline Portugal & 4,63 & IO,93 & $\mathrm{I} 2,22$ & II,97 & 9,94 \\
\hline Rumunjska & 2,36 & $\mathrm{I}, 75$ & 2,08 & 2,15 & 2,09 \\
\hline Slovenija & $\mathrm{Ig}, 73$ & $\mathrm{I} 7,89$ & I6,IO & $\mathrm{I} 7,82$ & $\mathrm{I} 7,89$ \\
\hline Slovačka & o,o6 & 0,05 & $\mathrm{O}, \mathrm{O} 4$ & 0,03 & 0,05 \\
\hline Finska & 19,62 & 20,72 & 21,83 & 24,08 & 21,56 \\
\hline Švedska & $\mathrm{I} 7, \mathrm{O} 5$ & $\mathrm{I} 4, \mathrm{I} 5$ & $\mathrm{I} 2, \mathrm{I} 3$ & II,56 & 13,72 \\
\hline UK & 27,76 & 15,42 & I0,36 & 9,47 & 15,75 \\
\hline
\end{tabular}

Izvor: Eurostat. 


\section{REFERENCE}

I. Bajo, A. i Petrušić, J., 20I4. Government guarantees and financial liabilities of state owned road transport companies in Croatia. Newsletter, br. 92. doi: 10.3326/nle.2014.92

2. Bajo, A. i Primorac, M., 20II. Government Guarantees and Public Debt in Croatia. Financial Theory and Practice, 35(3), str. 253-276. doi: 10.3326/fintp.35.3.I

3. Bajo, A. i Primorac, M., 20IIa. Do shipyards pose an obstacle to fiscal consolidation in Croatia? Newsletter, br. 64. Dostupno na: 〈http://www.ijf.hr/upload/files/file/ENG/newsletter/64.pdf〉.

4. Bajo, A. i Primorac, M., 20I4. Changes of methodological coverage of public debt and budget deficit in Croatia. Press Release, br. 70. doi: 10.3326/pr.2014.70

5. Bajo, A.i Primorac, M., 20I5. Should the Maastricht fiscal criteria be redefined? Newsletter,br. 99. doi: IO.3326/nle.2015.99

6. Bajo, A., Primorac, M. i Andabaka Badurina, A., 2011. Osnove upravljanja javnim dugom. Zagreb: Institut za javne financije.

7. CBS, 2015. Excessive Deficit Procedure Report, Republic of Croatia, April 2015 (ESA 2010). First Release, br. 12.I.2./I. Dostupno na: <http://www.dzs.hr/Hrv_Eng/publication/2015/I2-OIO2_OI_2OI5.htm>.

8. Cebotari, A. [et al.], 2009. Fiscal risks: sources, disclosure, and management. Washington: International Monetary Fund, Fiscal Affairs Department.

9. CNB, 2014. Bulletin, br. 205. Zagreb: Hrvatska narodna banka. Dostupno na: 〈http://www.hnb.hr/publikac/bilten/arhiv/bilten-205/ebilt205.pdf >.

Io.CNB, 2015. Bulletin, br. 217. Zagreb: Hrvatska narodna banka. Dostupno na: 〈http://www.hnb.hr/publikac/bilten/arhiv/bilten-217/ebilt217.pdf >.

II. Eurostat, 2013. European system of accounts: ESA 20IO. Dostupno na: <http://ec.europa.eu/eurostat/documents/3859598/5925693/KS-O2-13-269-EN.PDF/44cd9doIbc64-40e5-bd40-di7dfoc69334>.

12. Eurostat, 2014. Occasional Paper on Recent Eurostat's Activities Relating to the Task Force on Finance Statistics (TFFS). Meeting of the Task Force on Finance Statistics World Bank Headquarters, Washington DG, USA. March I3-I4, 2014. Dostupno na: <http://www.tffs.org/pdf/meet/20I4/eurostato3I4.pdf>.

13. Eurostat, 2014a. Manual on Government Deficit and Debt: Implementation of ESA 20Io. Dostupno na: <http://ec.europa.eu/eurostat/documents/3859598/5937189/KS-GQ-I4-OIO-EN.PDF/cI466fdeI4IC-4I8d-b7fI-eb8d5765aaId >.

I4. Eurostat, 2014b. Eurostat Supplementary Table for the Financial Crisis. Dostupno na: <http://ec.europa.eu/eurostat/documents/IO15O35/2022675/Background-note-fin-crisis-Oct2014-final.pdf $>$.

15. Eurostat, 2015. First time release of data on contingent liabilities and non-performing loans in EU Member States. News release, 26/2015. Dostupno na: <http://ec.europa.eu/eurostat/documents/299552I/6616449/2-I0022015-AP-EN.pdf/d75df6fe-Ioob-4ae7-aoge-oo40oedbi83a>.

I6. IFAC, 2013. Handbook of international public sector accounting pronouncements. New York: International Federation of Accountants.

17. IMF, 2005. Government Guarantees and Fiscal Risk. Washington: IMF. Dostupno na: $\langle$ https://www.imf.org/external/np/pp/eng/2005/O40105c.pdf $>$.

I8. IMF, 20I4. The Fiscal Transparency Code. Washington: IMF.

19. Ministarstvo financija, 2009. Godišnji izvještaj o izvršenju Državnog proračuna. Dostupno na: $\langle$ http://www.mfin.hr/hr/rebalans-proracuna-20og〉.

20.Ministarstvo financija, 20Io. Godišnji izvještaj o izvršenju Državnog proračuna za 20Io. Dostupno na: 〈http://www.mfin.hr/hr/godisnji-izvjestaj-o-izvrsenju-drzavnog-proracuna〉.

21. Ministarstvo financija, 20II. Godišnji izvještaj o izvršenju Državnog proračuna za 20II. godinu. Dostupno na: 〈http://www.mfin.hr/hr/drzavni-proracun-20II-godina〉.

22. Ministarstvo financija, 2012. Izvještaj o danim državnim jamstvima i izdacima po državnim jamstvima u 2012. godini. Dostupno na: 〈http://www.mfin.hr/hr/drzavni-proracun-2012-godina $>$.

23. Ministarstvo financija, 2013. Izvještaj o danim državnim jamstvima i izdacima po državnim jamstvima u 2013. godini. Dostupno na: <http://www.mfin.hr/hr/drzavni-proracun-20I3-godina $>$.

24. Ministarstvo financija, 20I4. Godišnje izvješće Ministarstva financija za 20I2. godinu. Dostupno na: 〈http://www.mfin.hr/adminmax/docs/Godisnjak\%2O2OI2.pdf〉.

25. Ministarstvo financija, 20I4a. Izvještaj o danim državnim jamstvima i izdacima po državnim jamstvima u 20I4. godini. Dostupno na: $\langle$ http://www.mfin.hr/hr/drzavni-proracun-2OI4-godina $>$. 
26. Ministarstvo financija, 20I5. Godišnje izvješće Ministarstva financija za 20I4. godinu. Dostupno na: 〈http://www.mfin.hr/adminmax/docs/Godisnjak\%2O2OI4..pdf〉.

27. Ministarstvo financija, 2015a. Polugodišnji izvještaj o izvršenju Državnog proračuna Republike Hrvatske za prvo polugodište 2015. godine. Draft proposal. Dostupno na: <https://vlada.gov.hr/UserDocsImages//Sjednice/2015/252\%20sjednica\%2OVlade//252\%2O\%2O3..pdf $>$.

28. Polackova, Brixi, H. i Schick, A., (ur.), 2002. Government at Risk: Contingent Liabilities and Fiscal Risk. World Bank i Oxford University Press.

29. Polackova, Brixi, H., 2004. Contingent Liabilities in New Member States. Fiscal surveillance in EMU: New Issues and Challenges. A workshop organized by the European Commission Directorate General for Economic affairs, Brussels, November I2, 2004.

30.Polackova, H., 1999. Contingent Government Liabilities: A Hidden Fiscal Risk. Finance and Development, 36(I), str. 46-49.

31. Ter-Minassian, T. (approved), 2005. Government Guarantees and Fiscal Risk. Washington: International Monetary Fund, Fiscal Affairs Department.

32. Thobani, M., 1999. Private Infrastructure, Public Risk. Finance and Development, 36(I), str. 50-53.

S engleskog preveo: $d r$. sc. Marko Primorac 